\title{
EDITORIAL
}

\section{O que é o prêmio mérito fonoaudiológico: depoimentos}

\author{
Brasília Maria Chiari, Léslie Piccolotto Ferreira, Mara Behlau, Iêda Chaves Pacheco Russo
}

“O Prêmio 'Mérito Fonoaudiológico' em minha opinião representa o endosso do compromisso de cada um de nós, pela comunidade fonoaudiológica.

Tendo sido a primeira agraciada pelo prêmio maior instituído pela Sociedade Brasileira de Fonoaudiologia, fiquei lisonjeada, muito feliz, pois ele referendou todo um pensar-agir ético, coerente e claro, característicos de minha trajetória em prol da Fonoaudiologia. Acredito que, para cada um de nós que o recebeu, foi uma grande emoção... dá uma sensação de pertencimento."

Brasília Maria Chiari - 2003

"Há alguns anos a Sociedade Brasileira de Fonoaudiologia estabeleceu o prêmio "Mérito Fonoaudiológico" e eu tive a honra de ser uma das recipientes desta distinção. Fico ainda comovida quando me lembro do momento em que recebi a notícia de minha premiação, pois não há nada melhor do que ser reconhecida pelos pares, pelos iguais, na distinção máxima da sociedade que nos congrega. A placa do mérito está em minha sala no CEV, bem ao alcance de meus olhos, e eu a reverencio diariamente como um compromisso de responsabilidade para com meus colegas, pacientes, clientes e assessorados. Este prêmio, acima de tudo, reforça um compromisso de excelência que assumi comigo mesma quando escolhi essa profissão. Após ter sido agraciada, passei a fazer parte da comissão julgadora e por duas vezes presidi esse processo. Isso me proporcionou estar nos bastidores e preparar a distinção de outros colegas, com também grande emoção. Celebrar a dedicação de nossos parceiros é hoje um dos melhores momentos do Congresso de Fonoaudiologia”.

Mara Behlau - 2004

"O título Mérito Fonoaudiógico é o reconhecimento da Fonoaudiologia com relação a seus pares. Ao mesmo tempo em que a pessoa que recebe se sente lisonjeada, esta, com seu exemplo, deixa um legado que contribui para o avanço da própria Fonoaudiologia. Por outro lado, é um título que estimula a superação de si mesmo e define novos compromissos e desafios. Em particular, no ano de 2005, ao ser agraciada com tal título, pude vivenciar a emoção de ver, no momento em que meu nome foi anunciado, a imagem de uma foto em que eu estava ao lado do Dr. Mauro Spinelli. Este havia falecido naquele ano, e tal imagem propiciou um sentimento de continuidade a obra por ele iniciada ao mesmo tempo em que pude manifestar toda a minha (nossa) gratidão.”

Léslie Piccolotto Ferreira - 2005

Em 2006 o Prêmio Mérito Fonoaudiológico foi atribuído, pelo voto direto da comunidade fonoaudiológica, in memoriam ao saudoso fonoaudiólogo Fabio Lessa.

“A grandeza não consiste em receber honras, mas em merecê-las.” - Aristóteles

“A SBFa concede a um fonoaudiólogo o Prêmio Mérito Fonoaudiológico, a fim de destacar a sua contribuição à dignidade da profissão. Reconhecer os pares é valorizar a própria classe diante da sociedade e fazer parte da trajetória de sua profissão. Este prêmio é um título de virtude dado a profissionais que atingiram o reconhecimento público das suas atividades. Este reconhecimento surge, muitas vezes, de uma postura ética para com a sociedade. A proclamação do nosso mérito é um exercício excelente para aumentar e mesmo para adquirir efetivamente esse mérito. A exaltação da nossa força atua como um estímulo permanente, fazendo com que realmente acreditemos nela e a ampliemos em benefício próprio e dos demais.

Na verdade, somos nós, por meio de nossas atitudes, que sabemos se somos ou não merecedores. Este merecimento tem de ser construído passo a passo, momento a momento, por toda uma vida! Está relacionado 
ao amor incondicional que precisamos sentir por nós mesmos e pelos nossos semelhantes. Somos aquilo que acreditamos ser. Aprendamos a agradecer por tudo o que temos, pois temos o que merecemos. O mérito é um reconhecimento que devemos a todos e sinto-me extremamente honrada por ter sido agraciada com este prêmio."

"Se você oferece parte de si mesmo para a vida, a parte que você recebe de volta será muito maior. Nunca se arrependa do passado, mas aprenda com ele. Nunca perca os seus sonhos de vista; uma pessoa que pode sonhar terá sempre esperança. Acredite em você mesmo; se o fizer, todos os demais o farão. Se você pode passar pela vida amando os outros, você atingiu o maior sucesso de todos.” - Judy Le Sage

Iêda Chaves Pacheco Russo - 2007 